\title{
INSIGHTS OF THE ANTIMICROBIAL ACTIVITY OF PIPERINE EXTRACTED FROM PIPER NIGRUM L.
}

\author{
AURELIAN CORNELIU MORARU ${ }^{1,2}$, IRINA ROȘCA ${ }^{3 *}$, BOGDAN CRĂCIUN $^{3}$, ALINA \\ NICOLESCU $^{3}$, ANCA E. CHIRIAC ${ }^{4}$, VICTOR VOICU ${ }^{1,5}$ \\ ${ }^{1}$ Romanian Academy, 125 Calea Victoriei, 010071, Bucharest, Romania \\ 2 “Dr. Iacob Czihac” Military Emergency Clinical Hospital, 7-9 General Berthelot Henri Mathias Street, Iaşi, Romania \\ 3 "Petru Poni" Institute of Macromolecular Chemistry, 41A Gr. Ghica Vodă Alley, 700487 Iaşi, Romania \\ 4 "Grigore T. Popa” University of Medicine and Pharmacy, 16 Universității Street, 700115, Iași, Romania \\ 5 "Carol Davila” University of Medicine and Pharmacy, 8 Floreasca Street, 014461, Bucharest, Romania
}

*corresponding author: rosca.irina@icmpp.ro

Manuscript received: May 2019

\begin{abstract}
The aim of this study was to present new insights of the antimicrobial activity of piperine extracted from Piper nigrum as compared to commercial piperine and to the activity of other similar compounds (namely: protocatechuic acid, L-ascorbic acid, L-tyrosine and syringic acid) and in synergism with ampicillin and amphotericin B. For this, piperine was isolated, purified and its structure and high purity were determined by NMR, FTIR, UV-Vis and TLC analysis. A concentration of 100 $\mathrm{mg} / \mathrm{mL}$ of piperine proved to have no cytotoxic effect on the opportunistic pathogens represented by Staphylococcus aureus and Escherichia coli, and was slightly efficient against Candida albicans. Nevertheless, piperine improved the ampicillin activity against $S$. aureus with $14 \%$ and in the same time decreased the activity of amphotericin B against $C$. albicans with $54.2 \%$, their antimicrobial properties being quite different compared to the commercial piperine.
\end{abstract}

\section{Rezumat}

Scopul acestui studiu este de a prezenta noi perspective asupra activității antimicrobiene a piperinei extrase din Piper nigrum în comparație cu piperina comercială și cu activitatea altor compuși similari (și anume: acid protocatechic, acid L-ascorbic, L- tirozină şi acid siringic) și în sinergism cu ampicilina și amfotericina B. Pentru aceasta, piperina a fost izolată, purifica tă și caracterizată prin analize RMN, FTIR, UV-Vis și TLC. O concentrație de piperină de $100 \mathrm{mg} / \mathrm{mL}$ nu a prezentat efect citotoxic asupra agenților conditionat patogeni reprezentați de Staphylococcus aureus și Escherichia coli și a fost eficient împotriva speciei Candida albicans. Cu toate acestea, piperina a îmbunătătit activitatea ampicilinei împotriva speciei $S$. aureus cu 14\% și, în același timp, a scăzut activitatea amfotericinei B împotriva levurii C. albicans cu 54,2\%, proprietățile ei antimicrobiene fiind destul de diferite față de piperina comercială.

Keywords: Piper nigrum, piperine, antimicrobial

\section{Introduction}

Piperine is the major alkaloid present in black pepper belonging to family Piperaceae, which is responsible for its hot and spicy taste and was first isolated from pepper extract by Hans Christian Ørsted in 1819 [1]. Pepper extracts contain alkaloids (e.g. piperine), terpenes, flavones and volatile oils (e.g. piperlyne) that exhibit sedating, detoxificativ, hypotensive, immunomodulatory, anti-oxidant, anti-asthmatic, anti-carcinogenic, anti-inflammatory, anti-ulcer, anti-amoebic activities [2-4].

Piperine has increased the bioavailability of many drugs such as: vasicine [5], theophylline and phenytoin [6], pyrazinamide and isoniazid [7], rifampicin [89], propranolol [10], pro-vitamin beta-carotene [11], nimesulide [12], cefotaxime sodium and amoxicillin [13], ampicillin and norfloxacin [14], gatifloxacin [15], docetaxel [16], curcumin [17-18], and acyclovir [19]. Based on cell, animal and human studies, piperine has been found to have properties and it is considered to have the potential to reduce drug dosage, cost of the drugs, the incidence of drug resistance and the risk of adverse drug reaction/ side effects [20].

According to literature, piperine proved to be efficient against Staphylococcus epidermidis and Salmonella enterica [21], Bacillus cereus and Bacillus subtilis [22], Staphylococcus aureus [23]. On the other hand, piperine did not show any antibacterial activity, but in combination with ciprofloxacin was efficient against Staphylococcus aureus ATCC29213 and MRSA isolates [24].

Within this context, the aim of this study was to obtain pure piperine from $P$. nigrum and to perform a screening of their antimicrobial properties compared with the commercial version and with similar drugs. The piperine was extracted, purified and characterized. In order to select the potential medical applications of the extract, there were conducted a series of biological 
assays: antibacterial and antifungal susceptibility test against three of the most known pathogens nowadays: Staphylococcus aureus ATCC25923, Escherichia coli ATCC25922 and Candida albicans ATCC10231. Moreover, it was investigated the interaction of the extract with an antibiotic and an antifungal drug used against the selected pathogens.

\section{Materials and Methods}

\section{Materials}

Black pepper (from BioWagner, country of origin: Sri Lanka), piperine (from Sigma, 97\%, used as reference), extraction thimbles (from Macherey-Nagel $\mathrm{GmbH}$, Germany), chloroform (from VWR Chemicals, 99.9\% GPR RECTAPUR), diethyl ether ( $\mathrm{Et}_{2} \mathrm{O}$ ) (from VWR Chemicals, 99.9\%), ethylic alcohol (EtOH) (from VWR Chemicals, 99\%), potassium hydroxide (KOH) (from Lach-Ner, 86.7\%), dichloromethane (DCM) (from Honeywell, Riedel-de Haen, CHROMASOLV $\geq$ 99.8\%), ethyl acetate (EtAc) (from VWR Chemicals, ACS, Reag. Ph. Eur.), double distilled water (obtained with FiSTREEM Cyclon WSC044.MH3.4 system), ultrapure water (obtained with TKA-GenPure 08.2204 system).

\section{Isolation and purification}

The extraction procedure was accomplished using slightly modified literature protocols [25-27], as follows: black pepper (160 g) was very fine milled using a Philips HR2860 grinder equipped with dry samples blades. The obtained black pepper fine powder was filled into the extraction thimble and sealed with a cotton stopper. The extraction cartridge loaded with the sample of interest was inserted into the Soxhlet extractor. The round bottom flask was filled with $320 \mathrm{~mL}$ chloroform, connected to Soxhlet extractor and inserted into silicone oil bath heated to $86^{\circ} \mathrm{C}$. To limit the extraction of by-products, the extraction process was stopped after 3.5 - 4 hours (two extraction cycles).

The resulting mixture solution was concentrated to dryness under vacuum using a rotary evaporator. The remaining residue as a viscous green-brownish oil was cooled to the freezer overnight. The next day, $50-100 \mathrm{~mL}$ of diethyl ether were added over the cold residue and the mixture was triturated until a yellow precipitate appeared. The precipitate was filtered, washed three times with cold diethyl ether and dried under vacuum, obtaining $5.5 \mathrm{~g}$ (3.44\% yield) pale yellow precipitate of piperine.

The precipitate was solubilized in a minimum volume of hot ethanol and the resulting solution was treated with $100 \mathrm{~mL}$ solution of $10 \% \mathrm{KOH}$ in warm ethanol and magnetically stirred for 30 minutes. Double distilled water was added to the solution in small portions, using the glass walls as support and the apparition of a fine yellow precipitate was observed. The mixture was diluted with double distilled water to a final volume of $800-1000 \mathrm{~mL}$ and kept in the refrigerator overnight to fully precipitate the piperine. The next day, the solution was filtered and the obtained yellow precipitate was washed twice with cold double distilled water and once with cold diethyl ether. The filtered precipitate was dried under vacuum using a drying oven for a couple of hours. After complete drying, the precipitate was solubilized in a minimum volume of hot ethanol, filtered and allowed to crystalize. After two hours was observed the apparition of small needle shaped crystals, but the solution was left overnight to fully crystallize. Further, yellow needle crystals were filtered and washed twice with cold ethanol. For the next crystallization, the crystals were solubilized in a minimal amount of hot ethanol, filtered, and the obtained solution was again allowed to crystallize overnight. The crystals were filtered, washed once with cold ethanol and twice with cold diethyl ether and dried under vacuum, obtaining $5.305 \mathrm{~g}$ (96\% yield) of pure yellow crystals of piperine.

Nuclear magnetic resonance (NMR) spectra were recorded on a Bruker Avance III 400 instrument (Bruker, Bremen, Germany), operated at 400 and $100 \mathrm{MHz}$ for ${ }^{1} \mathrm{H}$ and ${ }^{13} \mathrm{C}$ nuclei, respectively, at room temperature $\left(23^{\circ} \mathrm{C}\right)$. All chemical shifts are quoted on the $\delta$-scale in ppm, referred to tetramethylsilane (TMS) as internal standard and the coupling constants are given in $\mathrm{Hz}$.

Fourier-Transform Infrared Spectroscopy (FTIR). IR spectra were recorded on a FTIR Bruker Vertex 70 Spectrophotometer (Bruker, Bremen, Germany) equipped with a $\mathrm{ZnSe}$ single reflection ATR accessory. UV-Vis spectra were recorded with a LAMBDA 35 spectrophotometer (from Perkin Elmer Inc. USA).

Thin layer chromatography (TLC) was carried out on ALUGRAM Xtra SIL G/UV 254 plates (MachereyNagel GmbH, Germany).

Melting points were recorded on an A. Krüss Optronic Melting Point Meter KSPI (Germany).

The antimicrobial activity screening of the samples (piperine, standard piperine, protocatechuic acid, Lascorbic acid, L-tyrosine and syringic acid) was determined by the disk diffusion assay against six different reference strains: Staphylococcus aureus ATCC25923, Escherichia coli ATCC25922 and Candida albicans ATCC10231. The tested concentration was $100 \mathrm{mg} / \mathrm{mL}$ dissolved in DMSO. Afterwards, this concentration of the samples was mixed with ampicillin (100 mg/mL, Epigenetics, USA) and tested again against the bacterial reference strains and also with amphotericin B $(\mu \mathrm{g} / \mathrm{mL}$, Lonza, USA) and tested against the yeast strain.

All microorganisms were stored at $-80^{\circ} \mathrm{C}$ in $20-40 \%$ glycerol. The bacterial strains were refreshed in tryptic soy agar (TSA), and the yeast strain was refreshed with Sabouraud dextrose agar (SDA) at $36 \pm 1{ }^{\circ} \mathrm{C}$. The microbial suspensions were prepared with these cultures 
in sterile solution to obtain turbidity optically comparable to that of $0.5 \mathrm{McF}$ arland standards.

Volumes of $0.5 \mathrm{~mL}$ from each inoculum were spread on the Petri dishes. The sterilized paper disks were placed on the plates and an aliquot $(50 \mu \mathrm{L})$ of the samples were added. To evaluate the antimicrobial properties, the growth inhibition was measured under standard conditions after 24 hours of incubation at $36^{\circ} \mathrm{C}$. All tests were carried out in triplicate to verify the results [28]. After incubation, the diameters of the inhibition zones were measured by using Image J software.

\section{Results and Discussion}

\section{Melting point studies}

For the isolated and reference piperine were determined the melting points which must have an appropriate value of $131.5^{\circ} \mathrm{C}$ [29]. In the present study, isolated piperine undergoes melting between $130-131.5^{\circ} \mathrm{C}$, meanwhile, the reference piperine melts in the interval of $131-132.7^{\circ} \mathrm{C}$. Both melting point intervals are comparable with the literature value.

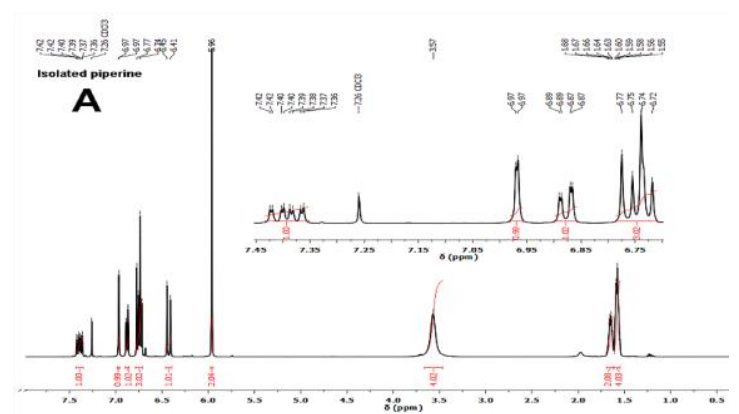

\section{TLC analysis}

Purity analysis of the isolated and reference piperine, appeared as single circular spot on the TLC plate ( $\mathrm{Rf}=0.69, \mathrm{DCM} / 40 \%$ ethyl acetate) under UV light at $254 \mathrm{~nm}$ and blue fluorescent spot at $365 \mathrm{~nm}$ for both studied compounds.

NMR spectra studies:

The chemical structures of both types of piperine were assigned by ${ }^{1} \mathrm{H}-\mathrm{NMR}$ and ${ }^{13} \mathrm{C}$-NMR spectroscopic methods. ${ }^{1} \mathrm{H}-\mathrm{NMR}\left(400 \mathrm{MHz}, \mathrm{CDCl}_{3}\right)$ spectra of isolated piperine (Figure 1A) confirms the chemical structure as follow: $\delta$ (ppm) 7.39 (ddd, $J=14.7$, 8.1, $\left.2.0 \mathrm{~Hz}, 1 \mathrm{H}, \mathrm{H}_{9}\right), 6.98$ (d, $J=1.5 \mathrm{~Hz}, 1 \mathrm{H}, \mathrm{H}_{13}$ ), $6.88\left(\mathrm{dd}, J=8.0,1.5 \mathrm{~Hz}, 1 \mathrm{H}, \mathrm{H}_{16}\right), 6.79-6.73$ (overlapped signals, $3 \mathrm{H}, \mathrm{H}_{10}, \mathrm{H}_{11}, \mathrm{H}_{15}$ ), 6.43 (d, $J=$ $\left.14.7 \mathrm{~Hz}, 1 \mathrm{H}, \mathrm{H}_{8}\right), 5.96$ (s, $\left.2 \mathrm{H}, \mathrm{H}_{14}\right), 3.57$ (as, $4 \mathrm{H}$, $\left.\mathrm{H}_{2}, \mathrm{H}_{6}\right), 1.66\left(\mathrm{~m}, 2 \mathrm{H}, \mathrm{H}_{4}\right), 1.57\left(\mathrm{~m}, 4 \mathrm{H}, \mathrm{H}_{3}, \mathrm{H}_{5}\right)$. As expected, the ${ }^{1} \mathrm{H}-\mathrm{NMR}\left(400 \mathrm{MHz}, \mathrm{CDCl}_{3}\right)$ spectrum of reference piperine (Figure 1B) is superposing completely over the isolated piperine spectrum: $\delta$ (ppm) 7.40 (ddd, $J=14.7,8.3,1.9 \mathrm{~Hz}, 1 \mathrm{H}, \mathrm{H}_{9}$ ), $6.97\left(\mathrm{~d}, J=1.5 \mathrm{~Hz}, 1 \mathrm{H}, \mathrm{H}_{13}\right), 6.88$ (dd, $J=8.0,1.6$ $\mathrm{Hz}, 1 \mathrm{H}, \mathrm{H}_{16}$ ), $6.78-6.72$ (overlapped signals, $3 \mathrm{H}$, $\left.\mathrm{H}_{10}, \mathrm{H}_{11}, \mathrm{H}_{15}\right), 6.43$ (d, $\left.J=14.6 \mathrm{~Hz}, 1 \mathrm{H}, \mathrm{H}_{8}\right), 5.96$ (s, 2H, $\left.\mathrm{H}_{14}\right), 3.57$ (as, 4H, $\left.\mathrm{H}_{2}, \mathrm{H}_{6}\right), 1.66(\mathrm{~m}, 2 \mathrm{H}$, $\left.\mathrm{H}_{4}\right), 1.58\left(\mathrm{~m}, 4 \mathrm{H}, \mathrm{H}_{3}, \mathrm{H}_{5}\right)$.

Figure 1.

${ }^{1} \mathrm{H}-\mathrm{NMR}\left(400 \mathrm{MHz}, \mathrm{CDCl}_{3}\right.$ ) spectra of isolated piperine (A) and reference piperine (B)

The perfect superposing of both spectra was also observed in ${ }^{13} \mathrm{C}-\mathrm{NMR}$ spectra with some few exceptions. The signal appeared at $\delta=26.13 \mathrm{ppm}$ from the isolated piperine spectra (Figure 2A) assigned for the $\mathrm{C} 2$ and $\mathrm{C} 6$ atoms showed a considerable decrease in intensity into ${ }^{13} \mathrm{C}$-NMR spectrum of reference piperine (Figure 2B) and also, the signal expected at $\delta=45.2 \mathrm{ppm}$ assigned for $\mathrm{C} 4$ atom is completely absent in the ${ }^{13} \mathrm{C}-\mathrm{NMR}$ spectrum of reference piperine, probably caused by the chirality of the molecule. All other signals are associated with the existing carbon atoms from the molecule. ${ }^{13} \mathrm{C}-\mathrm{NMR}(100$ $\mathrm{MHz}, \mathrm{CDCl} 3$ ) of isolated piperine: $\delta$ (ppm) 165.5 (C7), 148.1 (C17, C18), 142.9 (C9), 138.5 (C11), 130.9 (C12), 125.2 (C9), 122.6 (C16), 119.6 (C11), 108.4 (C15), 105.6 (C13), 101.2 (C14), 45.2 (C4), 26.1 (C2, C6), 24.6 (C3, C5) and ${ }^{13}$ C-NMR (100 $\mathrm{MHz}, \mathrm{CDCl} 3)$ of reference piperine: 165.4 (C7), 148.1 (C17, C18), 142.5 (C9), 138.2 (C11), 131.0 (C12), 125.3 (C9), 122.5 (C16), 120.0 (C11), 108.5 (C15), 105.6 (C13), 101.3 (C14), 26.1 (C2, C6), $24.6(\mathrm{C} 3, \mathrm{C} 5)$. 


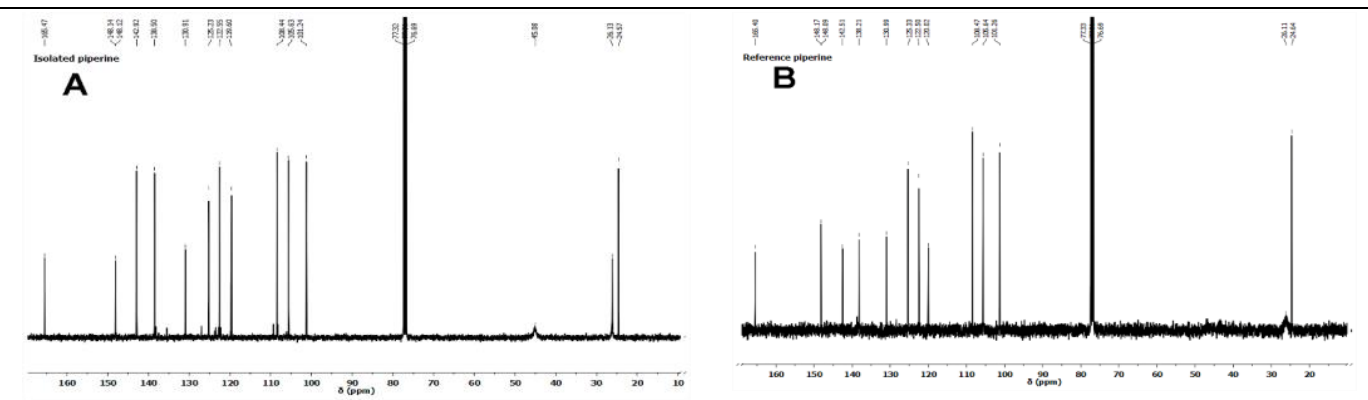

Figure 2.

${ }^{13} \mathrm{C}-\mathrm{NMR}\left(100 \mathrm{MHz}, \mathrm{CDCl}_{3}\right)$ spectra of isolated piperine (A) and reference piperine (B)

\section{IR spectra studies}

The structures of both types of piperine were confirmed by FTIR spectroscopy. As in the case of NMR spectra, both IR spectra of isolated and reference piperine are perfectly superposing (Figure 3). Obtained wavenumbers (ATR, $\mathrm{cm}^{-1}$ ) are assigned as follows: for isolated piperine: 3011 (arom. C-H st.), 2939, 2854 (aliph. C-H st.), 1632 (-CO-N-), 1610, 1582, 1489 (arom. C=C st.), 1441 (methylenedioxy $\mathrm{CH}_{2}$ bending), 1250, 1194 (=C-O-C asym. st.), 1028 (=C-O-C sym. st.), 995 (C-H bending of trans $\mathrm{CH}=\mathrm{CH}-), 928$ (C-O st.) and for reference piperine 3011 (arom. C-H st.), 2941, 2854 (aliph. C-H st.), 1631 (-CO-N-), 1610, 1581, 1489 (arom. C=C st.), 1440 (methylenedioxy $\mathrm{CH}_{2}$ bending), 1250, 1194 (=C-O-C asym. st.), 1028 (=C-O-C sym. st.), 996 (C-H bending of trans $-\mathrm{CH}=\mathrm{CH}-$ ), 928 (C-O st.).

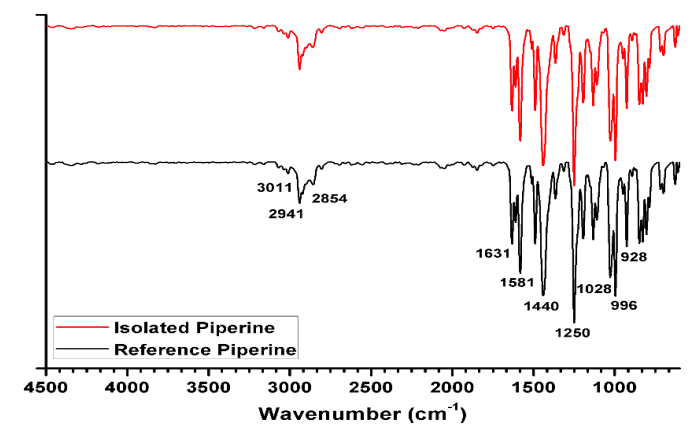

Figure 3.

ATR-FTIR overlaid spectra of isolated and reference piperine

\section{$U V$-Vis analysis}

The UV-Vis spectra of isolated and reference piperine (Figure 4) were recorded at the same concentration in water $\left(0.545 \times 10^{-5} \mathrm{M}\right)$ and were perfectly overlapping, presenting the UV absorption at $\lambda_{\max }$ value $=$ $342 \mathrm{~nm}$ which is in good correlation with the value reported in literature [30-32]. In the inserted graph it could be observed that the increasing or decreasing of the piperine concentration have no influence in the characteristic slope.

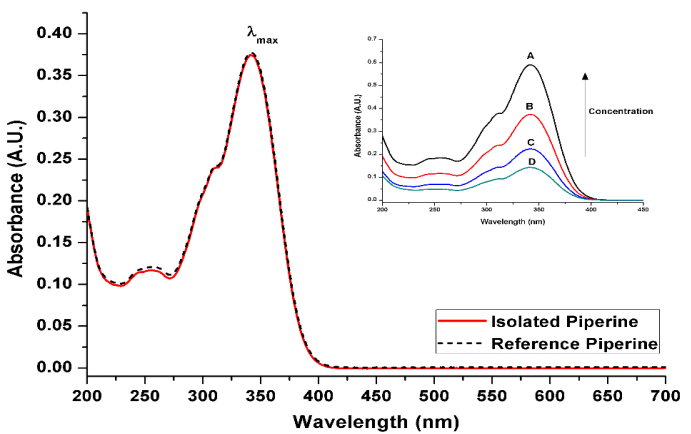

Figure 4.

Overlaid UV-Vis spectra of isolated and reference piperine $\left(\lambda_{\max }=342 \mathrm{~nm}, 0.545 \times 10^{-5} \mathrm{M}\right.$ in water $)$. Inset graphic represents UV-Vis spectra of isolated piperine at different concentrations

(A - $1.09 \times 10^{-5} \mathrm{M}, \mathrm{B}-0.545 \times 10^{-5} \mathrm{M}, \mathrm{C}-0.2725 \times 10^{-5} \mathrm{M}$ and $\mathrm{D}-0.1363 \times 10^{-5} \mathrm{M}$ )

\section{Antimicrobial activity}

According to series of studies regarding different black pepper extracts showed significant inhibitory effect against varied Gram-negative and Gram-positive bacteria, although some studies revealed that the black pepper have no antibacterial activity, which could be generally attributed to differences in plant varieties, microbiological methods, solvents used for compound extraction and tested microorganisms.

In this study, the antimicrobial activity was measured by the agar disk diffusion method [28] which supposes the addition of the compounds on the culture medium pre-inoculated with the microbial suspension, and measuring of the clear zone caused by the growth inhibition around the film disks after $24 \mathrm{~h}$ of incubation for the bacterial strains. The antimicrobial activity of the extracted piperine was compared to that of the commercial piperine, protocatehuic acid, syringic acid, L-ascorbic acid, L-tyrosine and syringic acid, and also with the combination of these compounds with Ampicillin and Amphotericin B.

Ampicillin is a penicillin beta-lactam antibiotic used in the treatment of bacterial infections caused by susceptible, Gram-positive and Gram-negative organisms. By binding to specific penicillin-binding proteins (PBPs) located inside the bacterial cell wall, ampicillin 
FARMACIA, 2019, Vol. 67, 6

inhibits the third and last stage of bacterial cell wall synthesis [33-34].

On the other hand, Amphotericin B showed a high order of in vitro activity against many species of fungi, especially against Candida albicans; it binds irreversibly to ergosterol, resulting in the disruption of membrane integrity and ultimately cell death [35]. Within this context, our results proved that the protocatechuic acid and the syringic acid were slightly efficient against $S$. aureus ATCC25923, E. coli ATCC25922 and C. albicans ATCC10231 (Table I). Syringic acid is a phenolic compound that proved to have antibacterial activity against Escherichia coli, Oenococcus oeni and Cronobacter sakazakii [36-38]. In vitro studies demonstrated that protocatechuic acid has the ability to inhibit bacterial growth and increase the synergistic effects of antibiotics hence reducing the possibility of resistance to drugs [39]. L-ascorbic acid has been shown to have an inhibitory effect on the growth of Staphylococcus aureus, Enterococcus fecalis, Helicobacter pylory, Campylobacter jejuni, Mycobacterium tuberculosis, Escherichia coli and Klebsiella pneumoniae [40-43] and even on fungi [44]. Furthermore, in vitro studies have shown that vitamin $\mathrm{C}$ can enhance the inhibitory effect of antibiotics such as levofloxacin [45] and azithromycin [46]. In our study L-ascorbic acid did not present antimicrobial activity and in combination with Ampicillin slightly increased the activity against $S$. aureus $(+8 \%)$ and decreased the activity against $E$. coli $(-19.9 \%)$ (Table I).

Table I

Antimicrobial activity of the tested compounds against the references strains ( $\mathrm{mm}$ )

\begin{tabular}{|c|c|c|c|c|c|c|}
\hline \multirow{2}{*}{ Tested compounds } & \multicolumn{2}{|c|}{ S. aureus ATCC25923 } & \multicolumn{2}{|c|}{ E. coli ATCC25623 } & \multicolumn{2}{|c|}{ C. albicans ATCC10231 } \\
\hline & Inhibition zone & $\% *$ & Inhibition zone & $\% *$ & Inhibition zone & $\% * *$ \\
\hline Ampicillin & $22.20 \pm 0.031$ & & $27.62 \pm 0.051$ & & Not tested & \\
\hline Amphotericin B & Not tested & & Not tested & & $17.25 \pm 0.123$ & \\
\hline Piperine & 0 & & 0 & & $01.90 \pm 0.012$ & \\
\hline Piperine + Ampicillin & $26.13 \pm 0.023$ & +14.00 & $27.46 \pm 0.015$ & -0.57 & Not tested & \\
\hline Piperine + Amphotericin B & Not tested & & Not tested & & $07.90 \pm 0.024$ & -54.2 \\
\hline Piperine Standard & 0 & & 0 & & 01.5 & \\
\hline Piperine Standard + Ampicillin & $22.83 \pm 0.05$ & +2.83 & $26.40 \pm 0.01$ & -4.41 & Not tested & \\
\hline Piperine Standard + Amphotericin B & Not tested & & Not tested & & $11.84 \pm 0.015$ & -31.36 \\
\hline Protocatehuic acid & $03.88 \pm 0.210$ & & $02.52 \pm 0.012$ & & $01.75 \pm 0.132$ & \\
\hline Protocatehuic acid + Ampicillin & $24.49 \pm 0.012$ & +10.31 & $25.00 \pm 0.023$ & -9.48 & Not tested & \\
\hline Protocatehuic acid + Amphotericin B & Not tested & & Not tested & & $13.64 \pm 0.010$ & -20.92 \\
\hline L-ascorbic acid & $00.75 \pm 0.011$ & & 0 & & 0 & \\
\hline L-ascorbic acid + Ampicillin & $23.98 \pm 0.012$ & +8.01 & $22.10 \pm 0.015$ & -19.9 & Not tested & \\
\hline L-ascorbic acid + Amphotericin B & Not tested & & Not tested & & $15.24 \pm 0.018$ & -11.65 \\
\hline L-tyrosine & 0 & & 0 & & $00.30 \pm 0.012$ & \\
\hline L-tyrosine + Ampicillin & $26.74 \pm 0.011$ & +20.45 & $23.78 \pm 0.013$ & -13.9 & Not tested & \\
\hline L-tyrosine + Amphotericin B & Not tested & & Not tested & & $12.83 \pm 0.015$ & -25.62 \\
\hline Syringic acid & $03.88 \pm 0.014$ & & $02.28 \pm 0.015$ & & $01.80 \pm 0.018$ & \\
\hline Syringic acid + Ampicillin & $21.75 \pm 0.013$ & $-2 \%$ & $23.02 \pm 0.012$ & -16.6 & Not tested & \\
\hline Syringic acid + Amphotericin B & Not tested & & Not tested & & $15.95 \pm 0.017$ & -4.53 \\
\hline
\end{tabular}

The combination of the tested compounds with the ampicillin slightly improved the antibiotic activity against $S$. aureus ATCC25923, the most notable activity proved to have the combination between ampicillin and L-tyrosine $(20.45 \%)$ and between ampicillin and piperine (14\%). The combination between syringic acid and ampicillin decrease the antibiotic activity with $2 \%$. The co-administration of piperine with ampicillin can cut down the frequency of administration and the related side effects. Piperine is a natural product used in food preparation with less toxicological consequences. This may also bring down the cost of the treatment of many infections which requires the use of antibiotics.
The same combinations determine a decrease of the antibiotic activity against $E$. coli ATCC25922 of $0.57 \%$ for piperine combined with ampicillin up to $19.98 \%$ for L-ascorbic acid combined with ampicillin (Table I).

Piperine presented a very low activity against $C$. albicans ATCC10231. However, the most dramatic decrease of activity was for the combination between the tested compounds and amphotericin B against $C$. albicans ATCC10231. In this case piperine managed to decrease the antifungal activity of amphotericin B up to $54.20 \%$ (Table I). Similar results were obtained for the other tested compounds, but in a lower percentage. 


\section{Conclusions}

In conclusion, we isolated and purified piperine from Piper nigrum, which had the same characteristics with the standard one, but a different in vitro activity. The isolated compound did not present antimicrobial activity by itself but improved the ampicillin activity against $S$. aureus ATCC25923 with $14 \%$ and in the same time decreased the activity of amphotericin B against $C$. albicans ATCC10231 with 54.2\%.

\section{Acknowledgement}

This work was supported by a grant of the Romanian Ministry of Research and Innovation, CCCDI UEFISCDI, project number PN-III-P1-1.2-PCCDI2017-0697/13PCCDI/2018, within PNCDI III.

\section{References}

1. Gorgani L, Mohammadi M, Najafpour GD, Nikzad M, Piperine - the bioactive compound of black pepper: From isolation to medicinal formulations. Compr Rev Food Sci Food Saf., 2017;16: 124-140.

2. Butt MS, Pasha I, Sultan MT, Randhawa MA, Saeed F, Ahmed W, Black pepper and health claims: a comprehensive treatise. Crit Rev Food Sci., 2012; 53875-53886.

3. Meghwal M, Goswami TK, Piper nigrum and piperine: an update. Phytother Res., 2013; 27: 1121-1130.

4. Yoon YC, Kim S, Kim MJ, Yang HJ, Rhyu M, Park J, Piperine, a component of black pepper, decreases eugenol-induced cAMP and calcium levels in non-chemosensory 3T3-L1 cells. FEBS Open Bio., 2015; 5: 20-25.

5. Atal CK, Zutshi U, Rao PG, Scientific evidence on the role of Ayurvedic herbals on bioavailability of drugs. J Ethnopharmacol., 1981; 4: 229-232.

6. Bano G, Amala V, Raina RK, Zutshi U, Chopra $\mathrm{CL}$, The effect of piperine on pharmacokinetics of phenytoin in healthy volunteers. Planta medica, 1987; 53: 568-569.

7. Zutshi U, A process for the preparation of pharmaceutical combination with enhanced activity for treatment of tuberculosis and leprosy. Indian Patent 1989; No. 1232/DEL/89.

8. Zutshi RK, Singh R, Zutshi U, Johri RK, Atal CK, Influence of piperine on rifampicin blood levels in patients of pulmonary tuberculosis. $J A P l, 1985 ; 33$ : 223-224.

9. Balakrishnan V, Varma S, Chatterji D, Piperine augments transcription inhibitory activity of rifampicin by several fold in Mycobacterium smegmatis. Curr Sci., 2001; 80: 1302-1305.

10. Bano G, Raina RK, Zutshi U, Bedi KL, Johri RK, Sharma SC, The effect of piperine on bioavailability and pharmacokinetics of propranololol and theophylline in healthy volunteers. Eur J Clin Pharmcol., 1991; 41: 615-617.

11. Badmaev V, Majeed M, Norkus EP, Piperine, an alkaloid derived from black pepper, increases serum response of beta-carotene during 14 days of oral beta-carotene supplementation. Nutr Res., 1999; 19: 381-388.

12. Gupta SK, Bansal P, Bhardwaj RK, Velpandian T, Comparative antinociceptive, anti-inflammatory and toxicity profile of nimesulide $v s$ nimesulide and piperine combination. Pharmacol Res., 2000; 41: 657-662.

13. Hiwale A, Dhuley J, Naik S, Effect of co-administration of piperine on pharmacokinetics of beta-lactam antibiotics in rats. Ind J Exp Biol., 2002; 40: 277-281.

14. Janakiraman K, Manavalan R, Studies on effect of piperine on oral bioavailability of ampicillin and norfloxacin. Afr J Tradit Complement Altern Med., 2008; 5: 257-262.

15. Patel S, Devada S, Patel H, Patel N, Bhavsar S, Thaker A, Influence of co-administration of piperine on pharmacokinetic profile of gatifloxacin in layer birds. Glob Vet., 2011; 7: 427-432.

16. Makhov P, Golovine K, Canter D, Kutikov A, Simhan J, Corlew MM, Uzzo RG, Kolenko VM, Co-administration of piperine and docetaxel results in improved antitumor efficacy via inhibition of CYP3A4 activity. Prostate, 2012; 72: 661-667.

17. Moorthi C, Krishnan K, Manavalan R, Kathiresan $\mathrm{K}$, Preparation and characterization of curcuminpiperine dual drug loaded nanoparticles. Asian Pac J Trop Biomed., 2012; 2: 841-848.

18. Tu Y, Fu J, Sun D, Zhang J, Yao N, Huang D, Shi $\mathrm{Z}$, Preparation, characterization and evaluation of curcumin with piperine-loaded cubosome nanoparticles. J Microencapsulation, 2014; 31:551-559.

19. Khatri S, Awasthi R, Piperine containing floating microspheres: an approach for drug targeting to the upper gastrointestinal tract. Drug Delivery Transl Res., 2016; 6: 299-307.

20. Meghwal M, Goswami TK, Piper nigrum and piperine: An update. Phytother Res., 2013; 27: 1121-1130.

21. Arora DS, Kaur J, Antimicrobial activity of spices. Int J Antimicrob Agents, 1999; 12: 257-262.

22. Singh G, Marimuthu P, Murali H, Bawa AS, Antioxidative and antibacterial potentials of essential oils and extracts isolated from various spice materials. J Food Saf., 2005; 25: 130-145.

23. Sangwan PL, Koul JL, Koul S, Reddy MV, Thota N, Khan IA, Kumar A, Kalia NP, Qazi GN, Piperine analogs as potent Staphylococcus aureus NorA efflux pump inhibitors. Bioorg Med Chem., 2008; 16: 9847-9857.

24. Khan IA, Mirza ZM, Kumar A, Verma V, Qazi GN, Piperine, a photochemical potentiator of ciprofloxacin against S. aureus. Antimicrob Agents Chemother., 2006; 50: 810-812.

25. Gorgani L, Mohammadi M, Najafpour G, Nikzad M, Piperine - The bioactive compound of black pepper: from isolation to medicinal formulations. Compr Rev Food Sci Food Saf., 2017; 16(1): 124-140.

26. Mihăilă B, Dinică RM, Tatu AL, Buzia OD, New insights in vitiligo treatments using bioactive compounds from Piper nigrum. Exp Ther Med., 2019; 17: 1039-1044.

27. Subramanian R, Subbramaniyan P, Noorul Ameen $\mathrm{J}$, Raj V, Double bypasses soxhlet apparatus for extraction of piperine from Piper nigrum. Arab J Chem., 2016; 9: S537-S540. 
28. Matuschek E, Brown DFJ, Kahlmeter G, Development of the EUCAST disk diffusion antimicrobial susceptibility testing method and its implementation in routine microbiology laboratories. Clin Microbiol Infect., 2014; 20: O255-O266.

29. Lide DR, CRC handbook of chemistry and physics: a ready-reference book of chemical and physical data. Boca Raton, Florida: CRC Press, 2003, 3-476.

30. Hashimoto K, Yaoi T, Koshiba H, Yoshida Y, Maoka T, Fujiwara Y, Yamamoto Y, Mori K, Photochemical isomerisation of piperine, a pungent constituent in pepper. Food Sci Technol Int., 1996; 2: 24-29.

31. Verzele M, Mussche P, Qureshi SA, High-performance liquid chromatographic analysis of the pungent principles of pepper and pepper extracts. J Chromatogr A, 1979; 172: 493-497.

32. Ternes W, Krause EL, Characterization and determination of piperine and piperine isomers in eggs. Anal BioanaL Chem., 2002; 374: 155-160.

33. Williamson $\mathrm{R}$, Hakenbeck $\mathrm{R}$, Tomasz A, In vivo interaction of beta-lactam antibiotics with the penicillin-binding proteins of Streptococcus pneumoniae. Antimicrob Agents Chemother., 1980; 18(4): 629-637.

34. Sala-Rabanal M, Loo DD, Hirayama BA, Turk E, Wright EM, Molecular interactions between dipeptides, drugs and the human intestinal $\mathrm{H}^{+}$-oligopeptide cotransporter hPEPT1. J Physiol., 2006; 574 (1): 149-166.

35. Laniado-Laborin R, Cabrales-Vargas MN, Amphotericin B: side effects and toxicity. Rev Iberoam Micol., 2009; 26(4): 223-227.

36. Zaldivar J, Ingram LO, Effect of organic acids on the growth and fermentation of ethanologenic Escherichia coli LY01. Biotechnol Bioeng., 1999; 66(4): 203-210.

37. Campos FM, Couto JA, Hogg TA, Influence of phenolic acids on growth and inactivation of Oenococcus oeni and Lactobacillus hilgardii. J Appl Microbiol., 2003; 94(2): 167-174.
38. Shi C, Sun Y, Zheng Z, Zhang X, Song K, Jia Z, Chen Y, Yang M, Liu X, Dong R, Xia X, Antimicrobial activity of syringic acid against Cronobacter sakazakii and its effect on cell membrane. Food Chem., 2016; 197: 100-106.

39. Jayaraman P, Sakharkar MK, Lim CS, Tang TH, Sakharkar KR, Activity and interactions of antibiotic and phytochemical combinations against Pseudomonas aeruginosa in vitro. Int J Biol Sci., 2010; 6(6): 556-568.

40. Zhang HM, Wakisaka N, Maeda O, Yamamoto T, Vitamin $\mathrm{C}$ inhibits the growth of a bacterial risk factor for gastric carcinoma: Helicobacter pylori. Cancer, 1997; 80: 1897-1903.

41. Isela S, Sergio N, Jose M, Rene H, Claudio C, Ascorbic acid on oral microbial growth and biofilm formation. J Pharm Innov., 2013; 2: 104-109.

42. Vilchèze C, Hartman T, Weinrick B, Jacobs WRJr., Mycobacterium tuberculosis is extraordinarily sensitive to killing by a Vitamin C-induced Fenton reaction. Nat Commun., 2013; 4: 1-25.

43. Verghese RJ, Mathew SK, David A, Antimicrobial activity of Vitamin C demonstrated on uropathogenic Escherichia coli and Klebsiella pneumoniae. J Curr Res Sci Med., 2017; 3: 88-93.

44. Govindappa Melappa, Shilpashree $\mathrm{Cb}$, Channabasava, Bharathi Prakash, In vitro antimitotic, antiproliferative and GC-MS studies on the methanolic extract of endophytic fungi, Penicillium species of Tabebuia Argentea Bur \& K. SCH. Farmacia, 2017; 65(2): 301-309.

45. El-Gebaly E, Essam T, Hashem S, El-Baky R, Effect of levofloxacin and Vitamin $\mathrm{C}$ on bacterial adherence and preformed biofilm on urethral catheter surfaces. J Microb Biochem Technol., 2012; 4: 131-136.

46. Biswas S, Thomas N, Mandal A, Mullick A, Chandra $\mathrm{D}$, Mukherjee $\mathrm{S}$, In vitro analysis of antibacterial activity of Vitamin $\mathrm{C}$ alone and in combination with antibiotics on Gram positive rod isolated from soil of a dumping site of Kolkata. Int J Pharm Biol Sci., 2013; 3: 101-110. 